\title{
Strategi Peningkatan Mutu SDM Pendidikan Berdasarkan Sistem Broad Based Education
}

\author{
Taufiqurrahman*
}

\begin{abstract}
Abstrak
Although the educational programe had been on going process since 56 years ago in Indonesia, but this state didn't has provided qualified human resources. Since 32 years ago of The New Order Government, educational sector development has never been placed as a prime priority of development. Its effect is Indonesian educational quality being worse than the other countries in southest Asia likes Malaysia, Pilipina, Singapura, and Thailand. Indonesia is being effected by dimentional multi crises since tvelve years ago and untill now, it is still degraded by its past time which avoided educational development. Moreover, the aother states which effected by the same problem like Indonesia could reform by paying attention greater toward educational development sector. They could reform faster and being better states bacause they have human good resource quality. By broad based education system and high based education system, we hope the quality of Indonesian human resources will be more better in the next.
\end{abstract}

Keywords: Educational quality, broad based education, high based education

Penulis adalah dosen Pasca Sarjana IAI Ibrahimi Situbondo

NO. 2. VOL. I. 2008

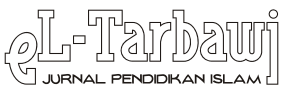




\section{A. Pendahuluan}

Mengapa paradigma baru pendidikan Indonesia perlu berorientasi pada sistem broad based education dan high based education? Terdapat 4 alasan mengapa sistem broad based education diperlukan yaitu: (1) alasan ekonomis. Karena ketidakmampuan orang tua atau faktor kemiskinan, maka tidak semua tamatan SD, SLTP dan SMU dapat melanjutkan pendidikan ke jenjang yang lebih tinggi. Umumnya mereka tidak memiliki keterampilan untuk bekerja mandiri dan kalaupun bekerja mereka mengerjakan pekerjaan kasar dengan upah yang rendah atau menjadi tenaga kerja keluarga di pedesaan, bahkan banyak yang menganggur; (2) alasan kemampuan intelektual. Secara nasional cukup banyak (sekitar 40 persen) anak yang dengan susah payah menyelesaikan SD dan tidak mempunyai kemampuan intelektual untuk mengikuti pelajaran di SLTP; (3) alasan tidak berminat; (4) banyak orang tua menyatakan, apa gunanya masuk SLTP karena bagi mereka yang tidak melanjutkan ke SMU dan SMK masuk SLTP sama sekali tidak berguna, karena tidak mempersiapkan para pelajar untuk bekerja, hanya untuk melanjutkan ke jenjang lebih tinggi (Drost, 2000:12). Hal yang sama juga dialami oleh lulusan SLTP dan SMU. Untuk mengakomodasi kebutuhan pendidikan bagi lulusan SD, SLTP dan SMU yang tidak dapat melanjutkan pendidikan ke jenjang yang lebih tinggi, sistem broad based education dalam bentuk pendidikan keterampilan sudah merupakan suatu kebutuhan, agar mereka memiliki life skill yang relevan dengan peluang kesempatan kerja yang tersedia.

Adapun latar belakang yang menjadi alasan sistem high based education sangat diperlukan adalah: (1) hasil UMPTN yang secara nasional rata-rata diikuti kurang lebih 600.000 siswa setiap tahun, ternyata hanya 10 persen yang lulus murni dan memiliki kematangan intelektual dan emosional untuk melanjutkan pendidikan di universitas. Walupun diakui bahwa di luar 10 persen tersebut banyak yang diluluskan untuk mengisi kursi yang tersedia, terutama di universitas-universitas luar Jawa dan universitas swasta; (2) untuk memenuhi kebutuhan SDM yang berkualitas, profesional baik untuk kebutuhan domestik maupun global; (3) merupakan human investment untuk mencetak SDM berkualitas, profesional yang mampu berkompetisi dalam konteks kerjasama dalam era globalisasi.

Tulisan ini ditujukan untuk mencoba mengungkap permasalahan 
yang dihadapi dunia pendidikan Indonesia pada saat ini, terutama yang berhubungan dengan rendahnya mutu SDM sebagai akibat dari mutu pendidikan yang rendah. Dalam persaingan pada era globalisasi ini, kemenangan ditentukan oleh mutu SDM. Mutu SDM itu sendiri ditentukan oleh pendidikan bermutu baik pada tingkat dasar, menengah maupun tinggi. Pendidikan memegang peranan kunci dalam usaha mencerdaskan kehidupan bangsa. Hal ini sesuai dengan cita-cita dan sumpah dari founding fathers kita untuk membangun suatu masyarakat Indonesia yang kuat, demokratis, mandiri, menghayati nilai-nilai untuk bersatu dalam kebhinekaan, menguasai ilmu dan teknologi, dan mampu bersaing dalam era kehidupan domestik dan global.

Kenyataan menunjukan, meskipun kegiatan pendidikan telah berlangsung di Indonesia selama 56 tahun, namun belum berhasil menyediakan SDM berkualitas. Selama 32 tahun pemerintahan Orde Baru, sektor pembangunan pendidikan tidak pernah ditempatkan menjadi prioritas pembangunan. Akibatnya mutu pendidikan Indonesia jauh tertinggal dibandingkan negara-negara tetangga seperti Malaysia, Pilipina, Singapura, Thailand. Apabila keempat negara ini telah berhasil mengirim tenaga-tenaga kerja terampil dan profesional untuk mengisi lowongan kerja yang tersedia di mancanegara, maka Indonesia baru dalam tingkat mengirim tenaga kerja untuk pekerjaan kasar seperti buruh pabrik, perkebunan , pembantu rumah tangga, dan lain-lain. Bangsa Indonesia dilanda krisis multi dimensi sejak empat tahun yang lalu dan hingga sekarang masih terpuruk akibat masa lalu yang mengabaikan pembangunan pendidikan. Sedangkan bangsa lain yang terkena krisis seperti Indonesia sudah bangkit kembali karena di masa lalu mereka menaruh perhatian besar terhadap sektor pembangunan pendidikan. Mereka bisa cepat bangkit karena memiliki kualitas SDM yang baik. Melalui sistem broad based education dan high based education, diharapkan mutu SDM Indonesia akan semakin baik. 


\section{B. Kajian Literatur}

\section{Beberapa tantangan dunia pendidikan di Indonesia saat ini}

\section{a. Heterogenitas tingkat pendidikan masyarakat}

Heterogenitas tingkat pendidikan masyarakat Indonesia dapat dilihat pada masyarakat di seluruh kepulauan Indonesia. Masih banyak penduduk yang buta aksara terutama di pedesaan, di samping mayoritas sudah dapat membaca dan menulis bahkan banyak yang sarjana. Pada jenjang sekolah dasar, terutama di pedesaan banyak anak-anak usia sekolah yang tidak pernah mengikuti sekolah dasar, putus sekolah, di samping banyak yang tamat sekolah dasar. Hal yang sama juga terjadi pada jenjang pendidikan SLTP dan SLTA. Penyebab utamanya adalah masalah kemiskinan dan ketidakmampuan orang tua menyekolahkan anaknya ke jenjang pendidikan yang lebih tinggi.

Kesimpulan yang dapat ditarik dari penjelasan di atas: (1) kesempatan untuk mengikuti pendidikan formal dan berbagai pelatihan keterampilan teknis bagi anak-anak (pemuda) sangat terbatas; (2) jumlah pemuda putus sekolah meningkat, bahkan banyak yang tidak pernah sekolah, (3) jumlah pemuda melek huruf fungsional sangat rendah, dan (4) mutu SDM generasi muda sangat buruk.

Sehubungandengan rendahnya tingkatpendidikan pemudadipedesaan, United Nations (dalam Borton E. Swanson, 1984: 17), mengemukakan beberapa permasalahan pokok sebagai berikut: (1) pada usia muda mereka sudah menjadi tenaga kerja keluarga atau bekerja pada orang lain; (2) waktu musim tanam atau panen, mereka bekerja melebihi jam kerja normal; (3) umumnya mereka menganggur pada pasca panen; (4) untuk memenuhi kebutuhan pokok keluarga mereka wajib kerja mencari upah; (5) mereka berkeluarga/kawin pada usia muda; (6) mereka tidak ingin berbaur dengan teman sebaya yang melek huruf, meskipun usia mereka sama; (7) merasa takut terhadap situasi belajar mengajar yang sifatnya formal; (8) mereka meninggalkan desa untuk menghindari lapangan kerja pertanian dan (9) mereka dihadapkan dengan lahan pertanian sempit yang mereka anggap akan membuat mereka tetap miskin.

Lebih lanjut, Mendiknas A. Malik Fajar pada pembukaan Temu 
Konsultasi Nasional "Pendidikan untuk Semua" yang dilaksanakan di Yogyakarta, Rabu 29 Aguastus 2001, mengemukakan beberapa tantangan yang dihadapi pendidikan Indonesia seperti terlihat dalam Tabel 1.

Tabel 1: Tantangan Dunia Pendidikan Indonesia Tahun 2001

\begin{tabular}{|l|l|l|l|}
\hline \multicolumn{1}{|c|}{ Permasalahan } & \multicolumn{1}{c|}{ Umur } & \multicolumn{1}{c|}{ Jumlah } & Keterangan \\
\hline $\begin{array}{l}\text { Anak yang tidak terlayani pada } \\
\text { pendidikan prasekolah }\end{array}$ & $4 \mathrm{~s} / \mathrm{d} 6$ tahun & 10.1 juta & $80 \%$ \\
\hline Buta Aksara & Diatas 10 tahun & $10 \mathrm{~s} / \mathrm{d} 16$ juta & $\begin{array}{l}\text { Faktor } \\
\text { kemiskinan }\end{array}$ \\
\hline $\begin{array}{l}\text { Anak usia pendidikan yang } \\
\text { tidak sekolah. }\end{array}$ & $7 \mathrm{~s} / \mathrm{d} 15$ tahun & 5.5 juta & $\begin{array}{l}\text { Faktor } \\
\text { kemiskinan }\end{array}$ \\
\hline
\end{tabular}

Sumber : Mediknas A. Malik Fajar dalam Harian Media Indonesia Jakarta, tanggal 31- $08-2001$.

\section{b. Keterpurukan perekonomian masyarakat}

Krisis ekonomi yang berawal dari krisis moneter tahun 1997, memiliki pengaruh signifikan terhadap dunia pendidikan Indonesia. Jumlah masyarakat miskin dan yang hidup dibawah garis kemiskinan meningkat. Pengangguran terbuka sudah mencapai 40 juta orang. Ditambah lagi pengangguran terselubung. Akibat langsung terhadap pendidikan adalah jumlah anak putus sekolah pada semua jenjang pendidikan meningkat. Indikator sosialnya adalah meningkatnya anak jalanan dan keluarga jalanan di kota-kota besar. Pada Pendidikan tinggi, banyak mahasiswa yang diharapkan menjadi calon intelektual muda, terpaksa cuti kuliah karena keterbatasan ekonomi keluarga. Bagi siswa SLTP dan SLTA yang putus sekolah, masalahnya akan lebih rumit. Rumit karena pada usia ini, emosi mereka belum stabil, tidak toleran terhadap orang lain, agresif secara fisik, rendah kesadaran akan kesalahan diri, dan menunjukkan perilaku yang egoistik (Sunaryo Kartadinata dan Nyoman Dantes, 1997: 65).

Apabila keluarga dan pemerintah tidak tanggap terhadap permasalahan ini, maka cepat atau lambat pengaruh lingkungan yang tidak kondusif akan membuat mereka terlibat pada kenakalan remaja, tawuran, penyalahgunaan narkoba, atau perilaku-perilaku kejahatan yang lebih ekstrim. Dengan demikian, dapat disimpulkan bahwa pembangunan pendidikan berhubungan 
erat dengan pembangunan ekonomi, terutama pembangunan ekonomi yang berakar pada ekonomi rakyat dan sumber daya domestik.

Mengenai hubungan tingkat pendidikan dengan peningkatan ekonomi ini, Hungtington ( 2001:86) mengemukakan bahwa tingkat perkembangan ekonomi yang lebih baik berpengaruh positif pada peningkatan jumlah publik yang memiliki pendidikan yang lebih tinggi dan masyarakat kelas menengah yang lebih besar. Keadaan ini akan melahirkan sikap kultur warga negara yang lebih baik, bertanggung jawab, dan memiliki kepuasan dan kompetensi yang mendukung terwujudnya demokrasi, seperti yang terlihat pada gambar berikut:

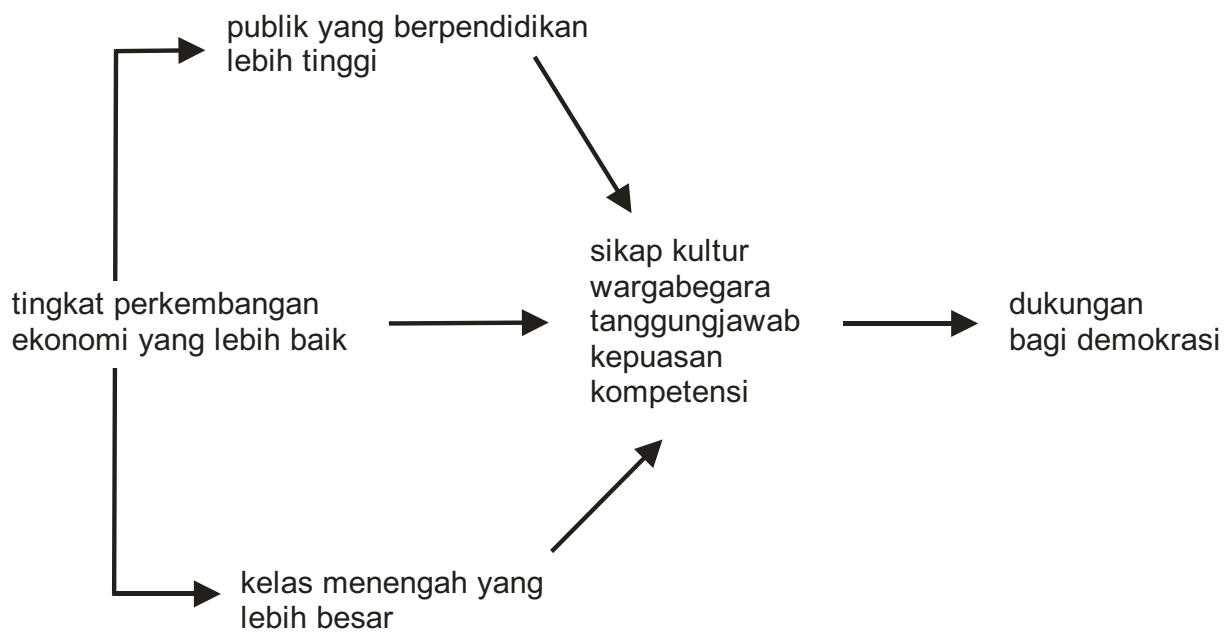

Gambar 1. Perkembangan Ekonomi Sebagai Sebuah Faktor Dalam Demokratisasi

Berkaitan dengan hubungan pendidikan dan perkembangan ekonomi ini, Edgar Faure pada makalahnya tentang "Pendidikan dan Hari Depan Umat Manusia" (dalam_Sindhunata (editor), 2001:4) menegaskan bahwa kecepatan perkembangan pendidikan dan pengajaran selalu selaras dengan kecepatan langkah perkembangan ekonomi. Jika ekonomi berkembang cepat, maka pendidikan pun cenderung cepat mengembangkan pengetahuan guna menyiapkan tenaga-tenaga yang dibutuhkan pada bidang pembangunan ekonomi. 


\section{c. Masalah Pemerataan Pendidikan}

Indonesia terdiri dari 13.000 kepulauan yang terbentang dari Sabang sampai Merauke. Dari keseluruhan pulaunya, baru kira-kira 6000 pulau yang dihuni manusia. Penduduk Indonesia diperkirakan 200 juta pada awal abad ke-21, dengan 560 kelompok etnis, yang mempunyai bahasa dan kebudayaan sendiri. Agama yang sudah diakui pemerintah ialah Islam, Kristen Protestan, Kristen Katolik, Hindu, Budha, dan Aliran kepercayaan kepada Tuhan Yang Maha Esa (Tampubolon, D,P. 2001 : 1-3).

Konsep "pendidikan untuk semua" mempunyai makna bahwa semua warga negara mempunyai hak untuk memperoleh pendidikan yang baik, juga mempunyai kewajiban untuk membangun pendidikan nasional yang bermutu. Konsekwensinya diperlukan pemerataan pendidikan. Apa saja kendala yang dapat kita pelajari dari pemerataan pendidikan ini? Paling sedikit terdapat lima kendala internal yang menghambat pemerataan pendidikan yaitu : (1) kendala geografis, artinya banyak pulau-pulau atau daerah-daerah yang sulit dijangkau pendidikan karena faktor komunikasi; (2) sarana pendidikan yang terbatas akibat alokasi dana yang sangat minim; (3) pemerintah masih mengutamakan pembangunan ekonomi sebagai prioritas, sementara pendidikan belum memperoleh porsi yang wajar; (4) tidak ada penghargaan yang wajar terhadap profesi guru, terutama yang menyangkut kesejahteraan, padahal kunci utama pendidikan bermutu ialah mutu guru itu sendiri; dan (5) perencanaan pendidikan yang sentralistik yang mengabaikan kemampuan dan karakteristik daerah.

\section{d. Globalisasi dan Paradigma Baru Pendidikan Indonesia Abad ke-21}

D.P. Tampubolon, (2001: 7-11) mengemukakan bahwa dengan perkembangan masyarakat industri dan pancaindustri, Indonesia berada di bawah pengaruh empat proses perkembangan sosial yang mendasar dalam abad ke-21, bahkan sesungguhnya sudah mulai dalam tiga dekade terakhir abad ke-20. Keempatnya dikatakan mendasar karena dampaknya dapat mengubah seluruh tata kehidupan. Keempat proses itu adalah:

- Globalisasi

- Industrialisasi 
- Asianisasi

- Sistem informasi canggih

Rangkuman akibat-akibat dan pengaruh keempat perubahan keempat proses tersebut dapat dilihat pada Tabel 2 berikut:

Tabel 2: Akibat Utama Globalisasi, Industrialisasi, Asianisasi, dan Sistem Informasi Canggih

\begin{tabular}{|c|c|c|}
\hline No & Proses & Akibat Utama \\
\hline 1 & Globalisasi & $\begin{array}{ll}\text { - } & \text { Keterbukaan } \\
\text { - } & \text { Demokratisasi } \\
\text { Persaingan dalam konteks kerja sama }\end{array}$ \\
\hline 2 & Industrialisasi & $\begin{array}{ll}\text { - } & \text { Rasionalitas } \\
\text { - } & \text { Dominasi KI (Kecerdasan Intelektual) } \\
\text { Sekularisme }\end{array}$ \\
\hline 3 & Asianisasi & $\begin{array}{ll}\text { - } & \text { Percaya diri Asia } \\
\text { - } & \text { Pengaruh Budaya Asia ke Barat dan } \\
& \text { bagian dunia }\end{array}$ \\
\hline 4 & Sistem Informasi canggih & $\begin{array}{ll} & \text { Kesaratderasan informasi } \\
\text { - } & \text { Perkembangan KI dan KE } \\
& \text { Simplikasi, efisiensi, dan efektifitas dalam } \\
\text { - } & \text { Bahasakasi menjadi kebutuhan pokok } \\
& \text { Perubahan sifat lembaga-lembaga } \\
& \text { pendidikan, khususnya pendidikan tinggi }\end{array}$ \\
\hline
\end{tabular}

Sumber: DP. Tampubolon, Perguruan Tinggi Bermutu (2001:11)

Globalisasi dapat diartikan sebagai proses saling berhubungan yang mendunia antarindividu, bangsa dan negara, serta berbagai organisasi kemasyarakatan, terutama perusahaan. Proses ini dibantu berbagai alat komunikasi dan transportasi yang berteknologi canggih, dibarengi kekuatan-kekuatan politik dan ekonomi serta nilai-nilai sosial-budaya yang saling mempengaruhi.

Perubahan mendasar akibat globalisasi ialah keterbukaan yang mengimplikasikan demokrasi dan kebebasan. Persaingan dalam bidang ekonomi akan semakin keras, tetapi selalu dalam konteks kerjasama. Demikian juga, industrialisasi yang menuntut rasionalitas, efektivitas dan efisiensi dalam semua segi kehidupan, termasuk penggunaan waktu. Semuanya harus diperhitungkan secara rasional, walaupun diakui bahwa 
rasionalitas dapat berbenturan dengan nilai-nilai tradisi yang emosional, termasuk nilai-nilai keagamaan. Dominasi rasio berkembang pesat melalui pendidikan. Dominasi rasio ini menyebabkan melemahnya kehidupan beragama, sebagaimana dapat dilihat dari berkembangnya sekularisme di dunia Barat yang memisahkan agama dari kehidupan bernegara.

Hal ini akan menimbulkan terjadinya dekadensi dalam kebudayaan Barat yang antara lain ditandai oleh semakin jauhnya individu dan masyarakat dari agama (Baumer: 1977 : 509). Naisbitt (1990:88) meramalkan bahwa asianisasi akan terjadi, dan sesungguhnya sudah mulai terlihat dalam dekade terakhir abad-20. Proses ini pada dasarnya adalah bagian dari globalisasi, dimana pengaruh Asia, terutama Asia Timur, Selatan, dan Tenggara, semakin kuat dan mendunia. Asia akan menjadi pusat perkembangan ekonomi, terutama karena kekayaan SDA dan jumlah SDM-nya serta kebudayaannya yang beraneka ragam dan bernilai tinggi. Perubahan mendasar yang dibawa oleh asianisasi ialah rasa percaya diri Asia yang semakin kuat. Bangsa-bangsa Asia tidak banyak lagi bergantung pada bangsa-bangsa Barat seperti dimasa lalu. Diantara bangsa-bangsaAsia, Cina akan memainkan peranan yang lebih besar. Keseratderasan informasi akan berpengaruh besar pada cara berfikir, berasa, serta berkomunikasi dengan bahasa. Kecerdasan intelektual dan kecerdasan emosional samasama berkembang. Kecepatan, simplikasi, efisiensi, dan efektivitas merupakan ciri-ciri utama bahasa yang komunikatif. Penguasaan bahasa, terutama Inggris, Mandarin, Perancis dan Jepang sangat perlu. Akhirnya keseratderasan informasi juga menyebabkan perubahan-perubahan cepat dalam berbagai bidang kehidupan, terutama ilmu dan teknologi.

\section{Pembahasan dan Analisis}

\section{Paradigma Baru Strategi Peningkatan MutuSDM Pendidikan Indonesia Abad ke-21}

Abad ke-21 adalah era globalisasi dengan ciri-ciri adanya saling keterbukaan dan ketergantungan antarnegara. Akibat saling keterbukaan dan ketergantungan ditambah dengan arus informasi yang sangat cepat maka kompetisi antarnegara pun akan semakin ketat terutama pada bidang ekonomi. Bagi Indonesia globalisasi ini tidak hanya memiliki dimensi 
domestik akan tetapi juga dimensi global. Dari segi dimensi domestik globalisasi ini memberi peluang positip terutama untuk mengadopsi dan menerapkan inovasi yang datang dari luar untuk meningkatkan peluang kesempatan kerja bagi masyarakat. Di samping itu dari segi keuntungan domestik, pengaruh globalisasi ini dapat mendidik masyarakat untuk memiliki pola pikir kosmopolitan dan pola tindak kompetitif, suka bekerja keras, mau belajar untuk meningkatkan keterampilan dan prestasi kerja. Dari segi global, kita hidup di dalam dunia yang terbuka, dunia yang tanpa batas. Perdagangan bebas serta makin meningkatnya kerjasama regional memerlukan manusia-manusia yang berkualitas tinggi. Kehidupan global merupakan tantangan sekaligus membuka peluang-peluang baru bagi pembangunan ekonomi dan bagi SDM Indonesia yang berkualitas tinggi untuk memperoleh kesempatan kerja di luar negeri. Di sinilah tantangan sekaligus peluang bagi peningkatan mutu pendidikan Indonesia baik untuk memenuhi SDM yang berkualitas bagi kebutuhan domestik maupun global.

Untuk menjawab tantangan sekaligus peluang kehidupan global di atas, diperlukan paradigma baru pendidikan. H.A.R. Tilar (2000:19-23) mengemukakan pokok-pokok paradigma baru pendidikan sebagai berikut: (1) pendidikan ditujukan untuk membentuk masyarakat Indonesia baru yang demokratis; (2) masyarakat demokratis memerlukan pendidikan yang dapat menumbuhkan individu dan masyarakat yang demokratis; (3) pendidikan diarahkan untuk mengembangkan tingkah laku yang menjawab tantangan internal dan global; (4) pendidikan harus mampu mengarahkan lahirnya suatu bangsa Indonesia yang bersatu serta demokratis; (5) di dalam menghadapi kehidupan global yang kompetitif dan inovatif, pendidikan harus mampu mengembangkan kemampuan berkompetisi di dalam rangka kerjasama; (6) pendidikan harus mampu mengembangkan kebhinekaan menuju kepada terciptanya suatu masyarakat Indonesia yang bersatu di atas kekayaan kebhinekaan masyarakat, dan (7) yang paling penting, pendidikan harus mampu meng-Indonesiakan masyarakat Indonesia sehingga setiap insan Indonesia merasa bangga menjadi warga negara Indonesia.

Konflik-konflik sosial, tindakan-tindakan diskriminasi, perilaku yang exklusif dan primordial muncul karena belum semua masyarakat merasa, menghayati dan bangga sebagai insan Indonesia. Dan di sinilah 
para pemimpin formal dan informal pada semua aspek kehidupan harus menjadi teladan.

Untuk mencapai tujuan ini diperlukan aktualisasi pendidikan nasional yang baru dengan prinsip-prinsip : (1) partisipasi masyarakat di dalam mengelola pendidikan (community based education); (2) demokratisasi proses pendidikan; (3) sumber daya pendidikan yang profesional; dan (4) sumber daya penunjang yang memadai.

Paradigma baru pendidikan di atas mengisyaratkan bahwa tanggung jawab pendidikan tidak lagi dipikulkan kepada sekolah, akan tetapi dikembalikan kepada masyarakat dalam arti sekolah dan masyarakat samasama memikul tanggung jawab. Dalam paradigma baru ini, masyarakat yang selama ini pasif terhadap pendidikan, tiba-tiba ditantang menjadi penanggung jawab pendidikan. Tanggung jawab ini tidak hanya sekedar memberikansumbanganuntukpembangunangedung sekolah danmembayar uang sekolah, akan tetapi yang lebih penting masyarakat ditantang untuk turut serta menentukan jenis pendidikan yang sesuai dengan kebutuhan, termasuk meningkatkan mutu pendidikan dan memikirkan kesejahteraan tenaga pendidik agar dapat memberikan pendidikan yang bermutu kepada peserta didik. Hal ini bukanlah sesuatu yang mudah karena banyak kendala yang mempengaruhi, antara lain: (1) bagi masyarakat hal ini merupakan masalah baru sehingga perlu proses sosialisasi; (2) bagi masyarakat yang tinggal di ibukota propinsi, kotamadya dan kabupaten, masalahnya lebih sederhana karena tingkat pendidikan dan ekonomi relatif baik, sehingga tidak sulit menyeleksi orang-orang yang akan duduk pada posisi tanggung jawab ini; (3) bagi masyarakat yang tinggal di ibukota kecamatan dan desa masalahnya menjadi rumit karena tingkat pendidikan masyarakatnya rendah dengan kondisi kehidupan miskin.

\section{Meningkatkan Mutu Sumber Daya Manusia melalui Aktualisasi Sistem Broad Based Education dan High Based Education.}

\section{a. Pendidikan yang Berorientasi pada Sistem Broad Based Education}

Pendidikan berdasarkan sistem broad based education ialah konsep pendidikan yang mengacu pada life skill. Tujuan utamanya adalah untuk mengakomodasi kebutuhan pendidikan masyarakat yang tidak dapat 
melanjutkan pendidikan ke jenjang yang lebih tinggi. Beberapa alasan mendasar yang perlu mendapat perhatian antara lain: a) tidak semua lulusan SD, SLTP, dan SMU memiliki potensi intelektual untuk belajar pada jenjang pendidikan yang lebih tinggi; b) SLTP, SMU, atau SMK yang ada masih bersifat umum, dan lulusannya dipersiapkan untuk melanjutkan pendidikan ke jenjang yang lebih tinggi, akibatnya lulusan SD yang tidak memiliki potensi intelektual untuk belajar di SLTP umum menjadi putus sekolah karena tidak tersedia SLTP keterampilan; c) ketidak-mampuan orang tua karena masalah kemiskinan merupakan faktor dominan yang mempengaruhi lulusan SD, SLTP, dan SMU tidak melanjutkan pendidikan ke jenjang yang lebih tinggi. Fakta mengungkapkan bahwa secara nasional setiap tahun terdapat sekitar 600.000 lulusan SD, dan jumlah yang sama juga terjadi pada SLTP dan SMU. Mayoritas atau sekitar $60 \%$ berasal dari keluarga miskin atau berpenghasilan rendah; d) untuk masuk pendidikan tinggi negeri harus lulus UMPTN, sedangkan yang lulus hanya $10 \%$ sesuai dengan daya tampung yang tersedia; c) biaya pada pendidikan tinggi swasta relatif lebih besar, hanya dapat dijangkau oleh masyarakat golongan menengah keatas, sedangkan masyarakat miskin yang jumlahnya mayoritas tidak mungkin menjangkaunya; d) banyak orang tua yang sudah memiliki persepsi bahwa untuk menjadi orang yang berhasil tidak harus memiliki gelar dari pendidikan tinggi; dan e) bahkan sarjana lulusan perguruan tinggi banyak yang menganggur.

Kenyataan-kenyataan diatas secara langsung menambah jumlah generasi muda yang menganggur. Mereka tidak memiliki keterampilan untuk bekerja mandiri terutama pada sektor informal. Pilihan terakhir adalah bekerja musiman sebagai buruh kasar dengan upah yang rendah, disamping ada yang bekerja sebagai tenaga kerja keluarga terutama dalam bidang pertanian. Akibatnya mayoritas menganggur dan tinggal di kotakota. Hidup menganggur membuat mereka frustrasi dan banyak terlibat dengan masalah kenakalan remaja, kriminalitas, tawuran, bahkan terlibat pada masalah narkoba. Biasanya apabila generasi muda terlibat pada masalah kenakalan remaja, tawuran dan penyalahgunaan NARKOBA, yang disalahkan adalah sekolah tidak bermutu, sistem pendidikan, guru, lingkungan, dan lain-lain. Secara empiris beberapa fakta menunjukkan bahwa perasaan kecewa, frustrasi dan pengaruh lingkungan yang kurang kondusif, menjadi faktor pendorong bagi mereka terlibat pada masalah-masalah diatas. Mengapa kecewa dan frustrasi? Karena mereka 
memaksakan diri atau setidak-tidaknya dipaksa orang tua untuk sekolah di SLTP atau SMU yang kurikulumnya hanya dapat diikuti oleh anak-anak pandai, sedangkan mereka tidak mampu mengikutinya. Akibatnya, mereka melakukan tindakan-tindakan yang bertentangan dengan nilai dan normanorma. Untuk bekerja tidak punya keterampilan, sehingga mereka lari dari kenyataan dan melakukan tindakan-tindakan destruktif.

Untuk memecahkan masalah ini, perlu pendidikan keterampilan yang sesuai dengan peluang kesempatan kerja yang dibutuhkan masyarakat dengan mempertimbangkan bakat dan minat, serta kemungkinan mereka dapat bekerja mandiri atau bekerja pada orang lain. Pendekatan ini sifatnya manusiawi, artinya bahwa terdapat pengakuan bahwa mereka memiliki potensi untuk dapat berkembang. Karena itu, gagasan untuk mendirikan SLTP keterampilan sudah merupakan kebutuhan yang dirasakan bagi anak-anak SD yang tidak mampu melanjutkan pendidikan di SLTP umum. Dan bagi lulusan SLTP perlu diarahkan melanjutkan pendidikan di SMK, sehingga SMU betul-betul diperuntukkan bagi anak-anak yang memiliki potensi akademis untuk melanjutkan pendidikan di universitas.

Masalah kesempatan kerja bagi angkatan kerja usia muda ini tidak saja disebabkan karena keterbatasan lowongan kerja yang tersedia, tetapi terutama karena umumnya mereka tidak siap pakai karena tidak memiliki kualifikasi keterampilan yang diharapkan. Keadaan ini dapat terjadi, karena sebagian besar dari mereka berasal dari sekolah umum dan bukan kejuruan. Bahkan tamatan dari sekolah kejuruanpun juga bukan jaminan untuk siap bekerja. Apabila pembangunan diartikan sebagai suatu perubahan berencana untuk meningkatkan mutu hidup masyarakat, maka pembangunan itu harus difokuskan pada penyediaan lapangan kerja dan SDM yang berkualitas. Oleh karena itu diperlukan suatu program pendidikan yang kami sebut dengan istilah "Program Pendidikan Untuk Mencari Nafkah" atau disingkat dengan "PUMN."

Pada hakekatnya PUMN dapat disama artikan dengan occupational education (Vasquez 1984:72), yaitu suatu programpendidikanyangmengacu kepada pekerjaan. Artinya, dalam program pendidikan semacam ini, warga terdidik diarahkan untuk siap bekerja, segera setelah menyelesaikan pendidikannya. Dengan kata lain, PUMN merupakan program pendidikan yang menghasilkan warga terdidik yang siap bekerja guna memperoleh penghasilan bagi kebutuhan nafkahnya. PUMN harus lebih menekankan 
pada aspek keahlian dan keterampilan teknis atau technical know how. Karena itu, PUMN harus berorientasi untuk menciptakan lapangan kerja employment generating dan untuk meningkatkan penghasilan income generating sebagaimana ditegaskan oleh Fuad Hasan (1985:1).

Lebih lanjut, UNESCO(1980:263), merumuskan latihan kerja sebagai: "Technical and vocational education may broadly defined as education to provide skills to enable students to enter a productive vocation and earn their livelihood. More specifically, it is to prepare a students for life, to earn a livelihood and to take up responsibilities of citizenship."

Dengan kata lain, PUMN merupakan program pendidikan yang menghasilkan warga terdidik yang siap bekerja guna memperoleh penghasilan bagi kebutuhan nafkahnya. Pada dasarnya PUMN, merupakan suatu sistem pendidikan nonformal yang bersifat pre-service training. Artinya, PUMN diselenggarakan di luar sistem pendidikan formal dimana warga belajarnya terdiri dari para pencari kerja. Bentuk PUMN yang dapat dijumpai adalah latihan kejuruan atau vocational training dan occupational training, serta kerja magang atau apprenticeship (Bambang Haryadi 1991:57). Warga terdidik yang dihasilkan PUMN diharapkan telah memiliki perilaku dengan kemampuan kognitif dan afektif yang setidaktidaknya, pada tingkatan (taxon) dapat menggunakan pengetahuannya (application) dan bersedia (responding) mengerjakan pekerjaan yang telah dipelajarinya (Blomm dalam Groundlund, 1970:20-22), serta memiliki kemampuan psikomotorik yang, setidak-tidaknya, mencapai tingkatan dapat mengerjakan dengan benar (mechanism) semua pekerjaan yang telah dipelajarinya ( Simson dalam Kibler et al, 1981:32).

Warga terdidik yang dihasilkan oleh PUMN, setelah bekerja diharapkan dapat memperoleh penghasilanuntuk memnuhi kebutuhan hidupnya. Pengertian penghasilan disini bukanlah sekedar penghasilan yang dapat memenuhi kebutuhan sehari-hari saja, melainkan penghasilan yang dapat diandalkan kesinambungannya dan dalam jumlah yang relatif cukup tinggi sehingga memungkinkan untuk selalu dapat memperbaiki mutu hidupnya (Havighurst 1979:122). Lebih lanjut, Comb and Ahmed (1984:108) menegaskan bahwa untuk mencapai tujuan pendidikan seperti yang dikehendaki, setiap penyelenggaraan PUMN harus disesuaikan dengan kebutuhan nyata, baik kebutuhan pokok yang dirasakan oleh setiap 
warga masyarakat setempat, maupun kebutuhan negara atau kebutuhan pembangunan dalam arti luas. Program PUMN sifatnya harus praktis, applicable dan sederhana. Namun yang lebih penting adalah materi ajar program PUMN itu harus sesuai dengan kebutuhan masyarakat baik felt needs, real needs dan expected-needs, terutama di dalam peningkatan income dan pembukaan peluang kerja baru.

PUMN sebagai suatu sistem pada hakekatnya merupakan suatu kesatuan dari bermacam-macam komponen (sub-sistem) yang saling berkaitan, terdiri dari warga terdidik atau raw-input, input alat atau instrument-input, input lingkungan atau environment-input dan warga terdidik yang merupakan output dari program tersebut (Muri Jusuf, 1982:37-38). Warga terdidik adalah hasil program pendidikan dan sekaligus tujuan yang ingin dicapai. Tentang hal ini, Jiyono( 1980:12) membedakannya dalam dua tahapan yaitu: hasil langsung (immediateoutcome) dan hasil akhir (ultimate-outcome). Hasil langsung program PUMN adalah perubahan perilaku warga terdidik yang diharapkan, sedang hasil akhir adalah relevansi atau keikutsertaan warga terdidik untuk membantu mengembangkan masyarakatnya dalam memenuhi kebutuhan tenaga kerja guna perbaikan kesejahteraan masyarakat. Gambaran PUMN sebagai suatu sistem dapat dilihat pada Gambar 2.

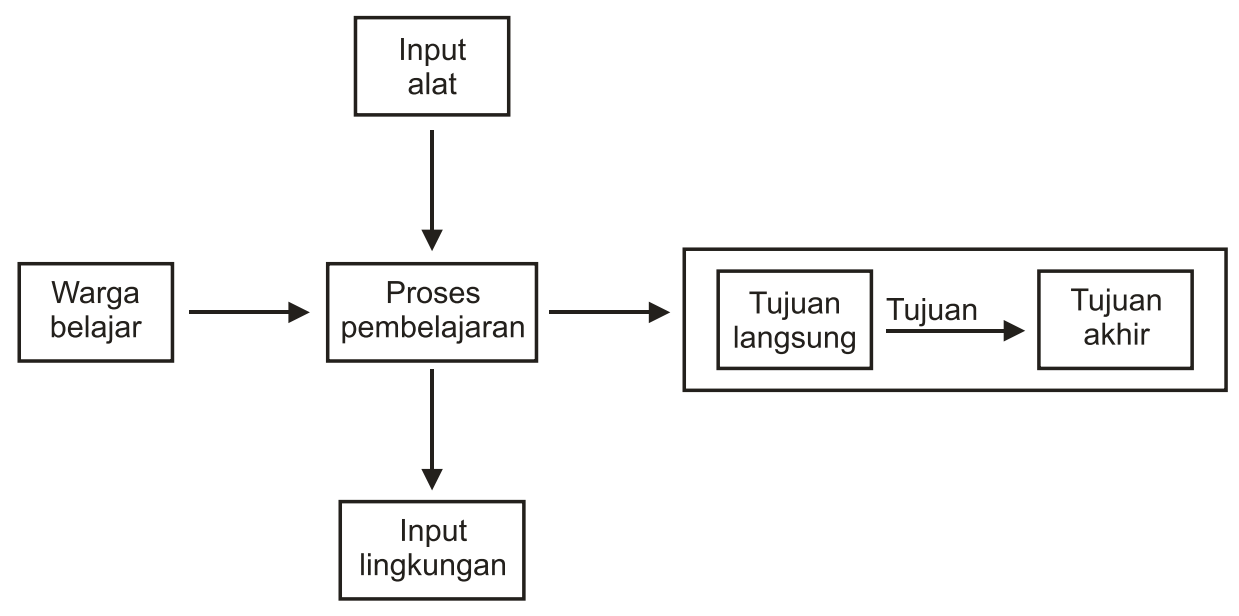

Gambar 2 PUMN Sebagai Suatu Sistem

UNESCO(dalam Sindhunata, 2001:116)mengemukakan keberhasilan 
pendidikan diukur dari hasil empat pilar pengalaman belajar itu, yakni (1) belajar mengetahui (learning to know); (2) belajar berbuat (learning to do);3) belajar hidup bersama (learning to live together) dan (4) belajar menjadi seseorang (learning to be). Idealnya dengan keterampilan dan pengetahuan yang diperoleh warga terdidik melalui PUMN itu, diharapkan peserta didik mampu membuka lapangan kerja untuk diri sendiri dan untuk orang lain-lain.

Untuk ini jenis dan orientasi program yang ditawarkan oleh PUMN harus dilakukan melalui kegiatan analisis kebutuhan latihan yang mengacu kepada kebutuhan pembangunan, baik pembangunan sektoral maupun regional di tingkat lokal, regional dan pembangunan nasional. Dan yang paling utama perlu kajian yang cermat tentang jenis usaha yang dapat dikembangkan di setiap lokasi, sejak tingkat desa, kecamatan, kabupaten dan propinsi, dengan mempertimbangkan sumberdaya yang tersedia (manusia dan alam) serta prospek pemasaran hasil usaha tersebut. Dengan menyadari bahwa Indonesia adalah negara agraria yang kaya akan sumber daya alam serta mayoritas penduduk termasuk generasi muda tinggal di desa, maka sudah saatnya pemerintah memberikan prioritas terhadap pembangunan industri pedesaan (skala kecil dan menengah) yang berbasis pada hasil produksi pertanian. Dengan demikian jenis dan orientasi PUMN dapat difokuskan pada pendidikan keterampilan yang sesuai dengan kebutuhan industri pedesaan seperti keterampilan mengolah bahan mentah menjadi bahan jadi, keterampilan berusaha tani, keterampilan mekanisasi pertanian, keterampilan melakukan usaha mandiri pada sektor informal dan lain-lain. Untuk bidang pekerjaan pada industri-industri besar di kota-kota maka jenis dan orientasi program PUMN harus mengutamakan pendidikan keterampilan yang dibutuhkan oleh industri-industri besar, seperti keterampilan bidang teknologi mekanik, listrik, otomatif, bangunan, tata niaga, dan aneka kejuruan lainnya.

Dengan demikian PUMN perlu berorientasi pada broad based curriculum, yaitu kurikulum yang sifatnya mendasar, berwawasan luas serta fleksibel, terutama untuk memenuhi kebutuhan dunia usaha/industri yang sangat sarat dengan perubahan dari waktu ke waktu. Subiyanto (2001:39-41) mengemukakan beberapa komponen broad based curriculum itu sebagai berikut : a) Komponen dasar. Komponen ini diharapkan dapat memberikan bekal kepada peserta didik kemampuan dasar yang kuat, luas, 
dan mendasar (akademik maupun pelatihan); b) Komponen kemampuan lanjutan. Komponen ini disusun atas dasar broad academic base and basic training atau komponen dasar. Komponen ini lebih mengarah pada kekhususan (spesifik) dari komponen dasar. Komponen ini berisi pembelajaran yang tekanannya pada skill development dan related theory. Perbandingan teori dan praktek tergantung pada karakteristik kejuruan yang dipelajari; c) Komponen keahlian. Komponen ini lebih spesifik bila dibandingkan dengan komponen lanjutan. Karena itu komponen ini lebih sangat labil dan berubah-ubah sesuai dengan perubahan lingkungan (misalnya teknologi); d) Artikulasi (internal dan ekternal). Kurikulum harus memiliki artikulasi internal dan eksternal. Ini berarti bahwa pengembangan kurikulum harus dinamis dan sesuai dengan filisofi dan misi. Dengan artikulasi yang baik, maka multy entry dan multy exit system dapat dilakukan sebagaimana mestinya. Proses seleksi terhadap calon peserta didik perlu didasarkan pada minat dan bakat. Demikian juga proses penempatannya harus sesuai dengan jenis keterampilan yang dipelajari. Dan untuk mereka yang akan bekerja mandiri perlu dibekali dengan alat peralatan yang diperlukan. Untuk ini perlu kerjasama dengan institusi lain, seperti perguruan tinggi, pusat-pusat pelatihan pemerintah/swasta, dan kursus-kursus; e) Pendidikan Jiwa Kewirausahaan. Di dalam kurikulum sudah waktunya memasukkan aspek kewirausahawan. Hal ini perlu agar peserta didik dapat dan mampu bekerja mandiri.

\section{b. Pendidikan yang berorientasi kepada High Based Education}

Tahun 1990, seorang staf pengajar Universitas Sumatera Utara yang baru selesai menyelesaikan pendidikan Doktor dibidang Teknik di Inggris menceritakan rasio perbandingan antara jumlah mahasiswa tugas belajar dari Indonesia, Malaysia dan Singapura di universitas-universitas yang ada di Inggris. Perbandingannya adalah dari Indonesia 1 orang, Malaysia 7 orang dan Singapura 14 orang di satu Universitas. Mahasiswa Indonesia adalah pegawai dari berbagai departemen, sedangkan dari Malaysia dan Singapore disamping pegawai negeri, juga tamatan SMU terbaik yang direkrut pemerintah sesuai dengan bidang ilmu yang dibutuhkan untuk pembangunan dan harus kembali kenegaranya setelah menyelesaikan studi. Hal yang sama mungkin terjadi di Amerika, Australia, Kanada, dan negara-negara lainnya. Memang diakui bahwa banyak mahasiswa 
Indonesia yang belajar di luar negeri atas biaya sendiri, tetapi tidak ada jaminan bahwa mereka harus kembali ke Indonesia setelah selesai studi. Bahkan sebaliknya kebanyakan memilih bekerja di luar negeri.

Apa yang dapat disimak dari keterangan tersebut di atas? Kesimpulannya adalah: 1) dari segi jumlah tenaga qualified, Indonesia ketinggalan dari kedua negara tersebut; 2) orientasi pendidikan pada kedua negara tersebut mengacu kepada mutu dalam arti global, sehingga kedua negara tersebut tidak perlu mendirikan universitas-universitas negeri dan swasta dengan biaya yang sangat mahal; 3) sebaliknya Indonesia kaya dengan perguruan tinggi negeri dan swasta tetapi kualitas lulusannya masih rendah; 4) sarjana ekonomi dari National University of Singapore, Universitas Kebangsaan Malaysia, dan University of The Philippines telah banyak mengisi lowongan pekerjaan yang bergensi di negara-negara industri maju, sedangkan lulusan dari perguruan tinggi Indonesia tidak memperoleh kesempatan tersebut.

Karenaitu, denganmenyadariketertinggalan kitapada mutupendidikan ini, maka sudah saatnya pemerintah menunjukkan kemauan politiknya dan menjadikan pendidikan sebagai pilar pembangunan Indonesia. Salah satu konsep pendidikan yang relevan yang perlu dilaksanakan, adalah sistem High Based Education.

Apa itu konsep High Based Education itu? Sebenarnya sistem High Based Education dalam dunia pendidikan tinggi atau lebih tepat disebut universitas bukanlah sesuatu yang baru. Hampir semua universitas di mancanegara termasuk Indonesiatelahmenentukan syarat-syaratbakuuntuk mengikuti studi di universitas. Untuk Indonesia, sistem itu dilaksanakan melalui UMPTN. Tujuan pokoknya adalah untuk menjaring calon-calon mahasiswa yang memiliki potensi menjadi insan akademis yaitu memiliki kecerdasan intelektual kecerdasan emosional dan kecerdasan spritual untuk mengikuti kuliah di universitas. Artinya calon mahasiswa ini dianggap sudah matang memulai studi di universitas. Mengenai pentingnya kematangan intelektual dan emosional untuk mengikuti studi di universitas, J. Drost, SJ ( 2000: 51-55) menyatakan bahwa walau staf dosen semua doktor dan amat pandai memberikan kuliah, perpustakaan lengkap, laboratorium amat canggih, selama mayoritas besar mahasiswa tidak mampu dan tidak siap menempuh studi di universitas, lulusan kebanyakan universitas kita tidak 
akan memenuhi tuntutan masyarakat abad ke-21. Mereka tidak memiliki potensi belajar untuk menempuh studi di universitas. Keluhan umum ialah bahwa lulusan luar negeri lebih dihargai dan lebih gampang mendapat pekerjaan. Maklum, lulusan Europa dan Australia dan kebanyakan lulusan Amerika telah mendapat gelar setingkat magister, sedangkan lulusan kita baru mendapat gelar setingkat bachelor. Sampai tahuan 70-an universitasuniversitas di Indonesia memakai pola dan sistem Eropa ( cq. Nederland). Namun kemudian diubah. Sistem Amerika dicangkokkan kepada pola Eropa. Di Amerika mahasiswa sebelum masuk universitas harus masuk lebih dahulu ke college yang berlangsung selama 3-4 tahun. Dalam college belum ada fakultas dan jurusan. Lulusan college mendapat gelar B.A. atau B.Sc., namun belum profesional, masih bersifat umum. Untuk menjadi profesional mereka harus mencapai gelar magister, kemudian doktor, di universitas atau graduate school. Di Indonesia stratum 1 memakai sistem Amerika yang dikawinkan dengan pola Eropa ialah bahwa sejak masuk universitas sudah harus memilih fakultas. Namun, waktu kuliah hanya empat tahun dan gelar sarjana, bukan sarjana yang masih umum, melainkan sudah terspesialisasi, sesuai dengan pola Nederland. Jadi, ada sarjana ekonomi, sarjana psikologi, sarjana pertanian, dsb. Namun, seharusnya dipakai sistem Amerika gelarnya setingkat B.A. dan belum profesional. Padahal pola Eropa dan sistemnya menuntut kuliah minimal 6 tahun dan gelar M.A., M.Sc., Diploma, Dokterandus, Ir., setingkat Magister. Sarjana kita seperti B.A. ekonomi, B.A. teknik, B.A. bahasa, B.A. pendidikan. Supaya lulusan universitas kita setingkat dengan luar negeri mereka harus mengambil dahulu gelar magister.

Apabila sistem high based education diaktualisasikan untuk meningkatkan mutu pendidikan tinggi dan mutu lulusannya, terutama memasuki milenium ketiga yang ditandai sebagai abad informasi, kompetisi yang sangat ketat, dan perkembangan ilmu pengetahuan dan teknologi yang sangat cepat ini, maka menurut hemat kami, diperlukan suatu perubahan kebijakan yang mendasar terutama untuk mengakomodasi kebutuhan pendidikan masyarakat yang memenuhi syarat melanjutkan pendidikan ke jenjang pendidikan tinggi. Perubahan kebijakan mendasar yang harus mendapat perhatian adalah sebagai berikut:

1. Perlu suatu kebijakan nasional tentang syarat-syarat baku yang 
berhubungan dengan kualifikasi calon mahasiswa dan mahasiswi yang dapat studi di universitas. Acuannya adalah potensi intelektual dan lulus UMPTN. Apabila yang lulus UMPTN hanya 10\% dari jumlah peserta, maka itulah yang diterima, dan didistribusikan kepada PTNPTN yang ada di Indonesia. Menerima mahasiswa yang tidak lulus hanya karena tempat masih tersedia di PTN terutama diluar Jawa, akan merendahkan mutu pendidikan dan mutu lulusan. Dan kebijakan seperti ini akan menimbulkan kesenjangan antara mutu pendidikan di pulau Jawa dan diluar jawa.

2. Sistem pendidikan di SMU harus benar-benar mempersiapkan siswa untuk melanjutkan pendidikan di universitas. Siap dalam konteks kecerdasan intelektual dan kecerdasan emosional. Ini berarti bahwa seleksi penerimaan siswanya harus benar-benar menjaring tammatan SLTP yang memiliki prestasi akademis yang unggul terutama dalam materi mata pelajaran matematika, fisika, kimia, biologi, dan bahasa inggris. Karena itu sudah waktunya Depdiknas mendorong tumbuhnya SMU dan SLTP unggul. Secara nasional jumlah mereka mencapai 30\%. Untuk sekolah-sekolah unggul ini perlu diberikan layanan pendidikan yang baik, termasuk kualitas gurunya beserta sistem kesejahteraannya dan pemberian bea siswa.

3. Dengan tidak mengurangi efektifitas seleksi mahasiswa melalui julur USBM, maka untuk mengakselerasi pemenuhan kebutuhan SDM yang berkualitas, maka tamatan SMU unggul dapat secara otomatis diterima menjadi mahasiswa di universitas.

4. Alternatiflain yaitu dengan mengadopsi sistem penerimaan mahasiswa yang dilaksanakan di Singapore. Siswa SMU yangmau melajutkan studi di universitas harus masuk college selama 2 tahun. Selama di college dengan kriteria-kriteria evaluasi yang sudah baku, mereka diseleksi. Yang memenuhi syarat secara langsung diterima di universitas, dan yang tidak memenuhi syarat diarahkan melanjutkan pendidikan di politektik. Perlu suatu kebijakan nasional untuk mengirim para lulusan SMU yang memiliki prestasi akademis yang excellent untuk studi di universitas bermutu di luar negeri pada berbagai disiplin ilmu yang dibutuhkan untuk pembangunan di Indonesia. Idealnya program ini dapat berlangsung selama 10 tahun dengan rata-rata pengiriman 1.000 
orang atau lebih per tahun. Alasannya ialah bahwa lebih baik mencetak SDM yang berkualitas sebanyak-banyaknya, dari pada membangun gedung-gedung pemerintah yang serba besar dan mewah.

5. Untuk meningkatkan mutu pendidikan tinggi di Indonesia diperlukan paradigma baru kerjasama antar pendidikan tinggi, baik dengan tinggi di dalam negeri maupun luar negeri, juga dengan berbagai penelitian terbaik, pemerintah daerah, termasuk dengan dunia usaha yang menjadi penyedia lapangan kerja.

\section{G. Penutup}

Berdasarkan uraian-uraian mengenai sistem broad based education dan high based education tersebut diatas maka sebagai penutup kami memberikan penekanan-penekanan sebagai berikut :

1. Baik orang tua terutama dunia pendidikan perlu menyadari bahwa, setiap anak memiliki potensi-potensi yang berbeda. Ada anak yang hanya memiliki potensi intelektual yang terbatas disamping ada yang memiliki potensi intelektual yang tinggi.

2. Untuk anak yang potensinya hanya rata-rata perlu dimasukkan pada pendidikan kejuruan yang akan memberikan kemungkinan kepadanya memiliki keterampilan untuk mencari nafkah. Pendidikan ini kami sebut dengan pendidikan untuk mencari nafkah (PUMN). Untuk ini pemerintah perlu lebih banyak mendirikan sekolah-sekolah kejuruan dan lembaga-lembaga pendidikan keterampilan dalam bentuk pendidikan non-formal.

3. Sekolah-sekolah kejuruan ini harus dirangsang lebih progresif dengan memasukkan sistem magang yang intensif dalam dunia usaha baik didalam negeri maupun diluar negeri.

4. Perlu proses sosialisasi kepada masyarakat agar timbul suatu kesadaran bahwa untuk menjadi orang yang berhasil bukan harus tamatan pendidikan tinggi.

5. Bagi anak-anak yang memiliki kemampuan intelektual yang tinggi perlu dirangsang dan difasilitasi untuk meneruskan pendidikan di universitas baik di dalam negeri maupun luar negeri. Untuk ini bagi 
anak yang berasal dari keluarga yang berpenghasilan rendah diberikan bea siswa.

\section{DAFTAR PUSTAKA}

BambangHaryadi, 1991.StrategiDasar MemerangiKemiskinandiIndonesia. Yogjakarta: Liberty.

Baumer, Franklin F. 1977. Modern European Thought: Continuity and Change in Ideas1600-1950. New York. Macmillan Publihsing Co. Inc

Burton E. Swason, 1984. Agricultural Extension. A Reference Manual (Second edition). Rome. Food and Agriculture Organizaton of the United Nations.

Combs, Phili H \& Manzoor Achmad, 1984. Memerangi Kemiskinan di PedesaanMelalui Pendidikan Non-Formal (diterjemahkan YIIS), Jakarta.

Harian Media Indonesia Jakarta, 28 Agustus 2001, hal. 27.

Fuad Hasan, "Tidak Bisa Ditunda-tunda Lagi Perluasan Pendidikan NonFormal” Harian Kompas, 1 Oktober 1985.

Groundlund E. Norman, 1970. Stating Behavior Objectives For Classroom Instruction. New York: The Macmillan Company

Havighurst, Robert J. 1979. Developmental Task And Education 3 Edition,New York. A Continuum Book.

Huntington Samuel P., 2001. Gelombang Demokratisasi Ketiga.Jakarta. Penerbit PT Pustaka Utama Grafiti.

Kibler, Robert J. et al. 1981. Objectives For Instruction and Evaluation. Boston: Allyn and Bacon, Inc.

J. Drost, Sl. 2000. Reformasi Pengajaran. Salah Asuhan Orangtua? Jakarta. Penerbit Gramedia Widisarana Indonesia.

Jiyono, 1980. Cara Mengukur Mutu Pendidikan. Analisa Pendidikan No. 2. Jakarta. Departemen Pendidikan dan Kebudayaan. 
Jusuf, Muri, 1982. Pengantar Ilmu Pendidikan. Jakarta. Ghalia Indonesia.

MPR RI. 1999. Ketetapan-Ketetapan MPR 1999. Dihimpun oleh Redaksi Sinar Grafika. Jakarta. Sinar Grafika.

Naisbit, John \& Aburdene, Patricia. 1990. Megatrend 2000: Sepuluh Arah Baru

1990-an. Diterjemahkan dari “Ten New Direction for the 1990! s Megatrend" oleh FX, Bujianto. Jakarta. Binarupa Aksara.

Subiyanto, 2001. Implikasi Penerapan Kurikulum SMK Edisi 1999 Terhadap Sistem Pengujian dan Sertifikasi ( dalam Majalah Ilmiah Prespektif Humaniora),

Forum Penelitian Pendidikan, Seni dan Kemanusiaan, Nomor 021/Tahun ke-VI/September/2001. ISSN o853-912X. Jakarta. Penerbit Swadaya Mandiri.

Sindhunata, (editor), 2001. Menggagas Pragigma Baru Pendidikan, Demokratisasi, Otonomi, Civil Society, Globalisasi. Jogjakarta. Penerbit Kanisius.

Sunaryo Kartasasmita dan Nyoman Dantes, 1997. Landasan-Landasan Pendidikan Sekolah Dasar. Departemen Pendidikan dan Kebudayaan, Direktirat Jenderal

Pendidikan Tinggi, Bagian Proyek Pengembangan Pendidikan Guru Sekolah Dasar.

Tampubolon Daulat P., 2001. Perguruan Tinggi Bermutu. Paradigma Baru Manajemen Pendidikan Tinggi Menghadapi Tantangan Abad ke-21. Jakarta, Penerbit Gramedia Pustaka Utama.

Tilaar, H.A.R, M.Sc.Ed., Dr, Prof, 2000. Paradigma Baru Pendidikan Nasional. Jakarta. Penerbit Rineka Cipta.

Unesco, 1980. Technical and Vocational Education in Asia Ociana. Bangkok. Bullentin of the Unesco Regional Office For Education in Asia and Oceana. Number 21, Bangkok.

Vasques, Corvaland,. 1984. Vocational Training For Disadvantage Youth in Developping Countries. Geneva: ILO. 